\title{
Different responses of soil respiration and its components to nitrogen and phosphorus addition in a subtropical secondary forest
}

\author{
Junjun Zhang ${ }^{1+}$, Yong $\mathrm{Li}^{2+}$, Jinsong Wang ${ }^{1 *}$, Weinan Chen ${ }^{1,3}$, Dashuan Tian ${ }^{1}$ and Shuli $\mathrm{Niu}^{1,3^{*}}$
}

\begin{abstract}
Background: Nitrogen $(\mathrm{N})$ and phosphorus $(\mathrm{P})$ deposition have largely affected soil respiration $\left(R_{\mathrm{s}}\right)$ in forest ecosystems. However, few studies have explored how $N$ and $P$ individually or in combination to influence $R_{s}$ and its components (autotrophic respiration, $R_{\mathrm{a}}$, heterotrophic respiration, $R_{\mathrm{h}}$ ), especially in highly P-limited subtropical forests. To address this question, we conducted a field manipulation experiment with $\mathrm{N}$ and/or $\mathrm{P}$ addition in a 50year-old subtropical secondary forest.

Results: We found that $\mathrm{N}$ addition on average reduced $R_{\mathrm{s}^{\prime}} R_{\mathrm{a}}$, and $R_{\mathrm{h}}$ by $15.2 \%, 15 \%$, and $11.7 \%$, respectively during 2-year field study. P addition had an inconsistent effect on $R_{\mathrm{a}}$, with $R_{\mathrm{a}}$ increasing by $50.5 \%$ in the first year but reducing by $26.6 \%$ in the second year. Moreover, $\mathrm{P}$ addition on average decreased $R_{\mathrm{h}}$ by $8.9 \%-30.9 \%$ and $R_{\mathrm{s}}$ by $6.7 \%-15.6 \%$ across 2 years. In contrast, $\mathrm{N}$ and $\mathrm{P}$ co-addition on average increased $R_{\mathrm{s}} R_{\mathrm{a}}$, and $R_{\mathrm{h}}$ by $1.9 \%, 7.9 \%$, and $2.1 \%$ during the experimental period. Though $R_{\mathrm{s}}$ and $R_{\mathrm{h}}$ were significantly correlated with soil temperature, their temperature sensitivities were not significantly changed by fertilization. $R_{\mathrm{a}}$ was predominantly regulated by soil nitrogen availability $\left(\mathrm{NH}_{4}{ }^{+}\right.$and $\left.\mathrm{NO}_{3}{ }^{-}\right)$, soil dissolved organic carbon (DOC), and enzyme activities, while the variation in $R_{\mathrm{h}}$ was mainly attributable to changes in soil microbial community composition and soil $\beta$-D-Cellubiosidase (CB) and $\beta$-Xylosidase (XYL) activities.
\end{abstract}

Conclusion: Our findings highlight the contrasting responses of $R_{\mathrm{s}}$ and its components to $\mathrm{N}$ or $\mathrm{P}$ addition against $\mathrm{N}$ and $\mathrm{P}$ co-addition, which should be differentially considered in biogeochemical models in order to improve prediction of forest carbon dynamics in the context of $\mathrm{N}$ and $\mathrm{P}$ enrichment in terrestrial ecosystems.

Keywords: Nitrogen deposition, Phosphorus enrichment, Heterotrophic respiration, Autotrophic respiration, Enzyme activities, Microbial community composition

\footnotetext{
* Correspondence: wangjinsong@igsnrr.ac.cn; sniu@igsnrr.ac.cn

†Junjun Zhang and Yong Li contributed equally to this work.

'Key Laboratory of Ecosystem Network Observation and Modeling, Institute of Geographic Sciences and Natural Resources Research, Chinese Academy of Sciences, Beijing 100101, China

Full list of author information is available at the end of the article
}

\section{Springer Open}

(c) The Author(s). 2021 Open Access This article is licensed under a Creative Commons Attribution 4.0 International License, which permits use, sharing, adaptation, distribution and reproduction in any medium or format, as long as you give appropriate credit to the original author(s) and the source, provide a link to the Creative Commons licence, and indicate if changes were made. The images or other third party material in this article are included in the article's Creative Commons licence, unless indicated otherwise in a credit line to the material. If material is not included in the article's Creative Commons licence and your intended use is not permitted by statutory regulation or exceeds the permitted use, you will need to obtain permission directly from the copyright holder. To view a copy of this licence, visit http://creativecommons.org/licenses/by/4.0/. 


\section{Introduction}

Soil respiration $\left(R_{\mathrm{s}}\right)$ is considered as an important process of carbon dioxide $\left(\mathrm{CO}_{2}\right)$ exchange between the atmosphere and soils in terrestrial carbon (C) cycling. A small change in soil $\mathrm{C}$ emissions can lead to a great impact on atmospheric $\mathrm{CO}_{2}$ concentration and thus global climate change (Xu and Shang 2016). Soil respiration includes two components, namely $\mathrm{CO}_{2}$ release originated from roots and rhizosphere microbes (autotrophic respiration, $R_{\mathrm{a}}$ ) that use $\mathrm{C}$ fixed by plant photosynthesis, and $\mathrm{CO}_{2}$ emission derived from microbial decomposition of plant litter and soil organic matter (heterotrophic respiration, $R_{\mathrm{h}}$ ) (Subke et al. 2006). Atmospheric nitrogen $(\mathrm{N})$ deposition has been predicted to increase by $50 \%-100 \%$ by 2030 compared with 2000 and it is expected to exacerbate in many areas around the world, especially in the East and South Asia (Reay et al. 2008). The evidence is mounting that $\mathrm{N}$ enrichment can affect $R_{\mathrm{s}}$ by affecting soil nutrient availability, inducing soil acidification, and influencing plant growth and microbial activity (Tian and Niu 2015; Peng et al. 2017b; Wang et al. 2019b). Therefore, knowledge of responses of $R_{\mathrm{s}}$ and its components to the increase in $\mathrm{N}$ availability is critical to improve our ability to quantify ecosystem $\mathrm{C}$ balance, model terrestrial $\mathrm{C}$ cycling, and predict $\mathrm{C}$ climate feedbacks (Robertson et al. 2013).

Considerable efforts have been devoted to explore the influence of $\mathrm{N}$ supply on $R_{\mathrm{s}}$ in forest ecosystems, which have high productivity and store vast amounts of $C$ in soils (Pan et al. 2011; Sun et al. 2019). However, the results from field observations (Zhao et al. 2018), models (Devaraju et al. 2016), and meta-analyses (Zhou et al. 2014; Chen et al. 2016; Zhong et al. 2016; Feng and Zhu 2019) are inconsistent and controversial, exhibiting positive (Zhou et al. 2014; Chen et al. 2019; Wang et al. 2019a), negative (Wang et al. 2017a; Zhou et al. 2018; Song et al. 2020) and negligible effects on $R_{\mathrm{s}}$ (Zhong et al. 2016; Liu et al. 2017; Wei et al. 2020). Such discrepancies are largely ascribed to the different sensitivities of plant roots and soil micro-organisms to $\mathrm{N}$ enrichment, resulting in uncertainties and inconsistent results of $R_{\mathrm{a}}$ and $R_{\mathrm{h}}$ in response to $\mathrm{N}$ enrichment. For instance, a global meta-analysis has reported that $\mathrm{N}$ addition generally decreases $R_{\mathrm{h}}$ in diverse ecosystems (Zhang et al. 2018), which is likely due to decreased soil microbial biomass, suppression of extracellular enzyme activities, and changes in microbial composition that may increase microbial $\mathrm{C}$ use efficiency ( $\mathrm{Li}$ et al. 2018; Wang et al. 2018; Zhang et al. 2018; Liu et al. 2019; Ma et al. 2020). In contrast, the response of $R_{\mathrm{a}}$ to $\mathrm{N}$ enrichment is disparate. Increasing $\mathrm{N}$ availability can alleviate $\mathrm{N}$ restriction on root growth and thus promoting $R_{\mathrm{a}}$ (Cheng et al. 2015; Li et al. 2017). However, excessive $\mathrm{N}$ may decrease $R_{\mathrm{a}}$ because the photosynthetic $\mathrm{C}$ allocated to belowground would decrease (Olsson et al. 2005; Adair et al. 2009). Moreover, excess $\mathrm{N}$ enrichment could give rise to ammonium toxicity and acid cation toxicity (Li et al. 2018), also resulting in the decrease of $R_{\mathrm{a}}$. Nevertheless, most of those studies were conducted in $\mathrm{N}$ limited forests (Savage et al. 2013; Sun et al. 2014), tropical and subtropical forests where are highly phosphorus (P) limited instead of $\mathrm{N}$ limited are poorly understood and largely uncertain regarding the effects of $\mathrm{N}$ addition on $R_{\mathrm{s}}$ and its components ( $\mathrm{Li}$ et al. 2016; Wei et al. 2020).

It is generally recognized that plant growth is limited by $\mathrm{P}$ in tropical and subtropical forests, because soils in these regions are particularly old, highly weathered and consequently poor in available P (Vitousek et al. 2010; Cleveland et al. 2011). Moreover, increasing $N$ availability with $\mathrm{N}$ deposition may shift from $\mathrm{N}$ to $\mathrm{P}$ limitation in many forest ecosystems (Zeng and Wang 2015; Li et al. 2016; Wang et al. 2017b; Camenzind et al. 2018). Thus, $\mathrm{P}$ addition is likely to alleviate soil $\mathrm{P}$ limitation and accelerate root growth and $R_{\mathrm{a}}$ in forests (Naples and Fisk 2010). Similarly, increasing available $\mathrm{P}$ may stimulate $R_{\mathrm{h}}$ by enhancing microbial growth and activities (Ilstedt and Singh 2005) or inhibit $R_{\mathrm{h}}$ largely due to soil acidification and shifts in soil microbial community (Li et al. 2018; Feng and Zhu 2019). Multiple evidence suggests that the impacts of $\mathrm{P}$ enrichment on $R_{\mathrm{a}}$ and $R_{\mathrm{h}}$ are very complex in the context of $\mathrm{N}$ deposition (Liu et al. 2019). Nonetheless, the mechanisms underlying the divergent responses of $R_{\mathrm{a}}$ and $R_{\mathrm{h}}$ to $\mathrm{P}$ addition and its interaction with $\mathrm{N}$ addition are far from clear, which deserves further investigation, especially in the highly $\mathrm{P}$ limited forests.

$R_{\mathrm{a}}$ and $R_{\mathrm{h}}$ are determined by a complex interaction of controlling factors, including soil temperature and moisture, soil pH, soil nutrient availability, substrate supply, and soil microbial community (Zhang et al. 2014; Cheng et al. 2015; Li et al. 2018; Tang et al. 2020). Among them, soil temperature is a dominant factor that affects $R_{\mathrm{s}}$ and its components in forests (Wagai et al. 2013; Miao et al. 2020; Peng et al. 2020). Temperature sensitivity of $R_{\mathrm{S}}\left(Q_{10}\right)$, which is the relative change of soil $\mathrm{CO}_{2}$ efflux for a $10^{\circ} \mathrm{C}$ increase in soil temperature, is a critical parameter in assessing climate- $\mathrm{C}$ feedbacks in $\mathrm{C}$ cycle models (Davidson and Janssens 2006). A variety of factors can influence $Q_{10}$ value, including soil moisture, substrate and nutrient availability, soil enzyme activity and microbial community composition (Curiel Yuste et al. 2004; Wagai et al. 2013; Dong et al. 2020). Both N and $\mathrm{P}$ enrichments could directly and indirectly change these factors, thereby influencing $Q_{10}$ values of $R_{\mathrm{s}}$ and its components. However, inconsistent results regarding the response of $Q_{10}$ to $\mathrm{N}$ addition have been found in previous studies, including increase (Deng et al. 2010), 
decrease (Zhang et al. 2014), or no change (Jia et al. 2012). Although the previous studies have investigated the response of $Q_{10}$ in $R_{\mathrm{s}}$ to $\mathrm{N}$ addition in temperate forests (Sun et al. 2014), few studies have addressed the effects of $\mathrm{P}$ addition and its association with $\mathrm{N}$ addition on $Q_{10}$ values of $R_{\mathrm{s}}$ and its components in tropical and subtropical forests.

We conducted a 3-year field $\mathrm{N}$ and $\mathrm{P}$ addition experiment in a subtropical secondary forest, which is located in the transition belt from the warm temperate to subtropical forest of a mountain ecosystem. In this study, we measured soil $R_{\mathrm{s}}, R_{\mathrm{a}}$ and $R_{\mathrm{h}}$ and explored their relationships with soil physicochemical properties, soil microbial biomass, cellulose degrading enzyme activities, microbial community composition under $\mathrm{N}$ and $\mathrm{P}$ enrichment. The objectives of this work were (1) to investigate the effects of $\mathrm{N}$ and $\mathrm{P}$ enrichment and their interaction on $R_{\mathrm{s}}$ and its components; (2) to explore the biotic and abiotic mechanisms underlying the responses of $R_{\mathrm{s}}, R_{\mathrm{a}}$ and $R_{\mathrm{h}}$ to $\mathrm{N}$ and $\mathrm{P}$ enrichment; (3) to reveal the $Q_{10}$ of $R_{\mathrm{a}}$ and $R_{\mathrm{h}}$ in response to $\mathrm{N}$ and $\mathrm{P}$ enrichment in this subtropical forest ecosystem.

\section{Materials and methods}

\section{Site description}

This study was carried out at the Jigong Mountain Biosphere Reserve in the south of Henan Province, China $\left(31^{\circ} 51^{\prime} 58^{\prime \prime} \mathrm{N}, 114^{\circ} 5^{\prime} 12^{\prime \prime} \mathrm{E}\right)$. The region is characterized by a transitional climate, which is from warm temperate to subtropical climate. The annual mean air temperature is $15.2^{\circ} \mathrm{C}$. The mean lowest temperature in January is approximately $1.9^{\circ} \mathrm{C}$, and the mean highest temperature in July is $27.5^{\circ} \mathrm{C}$. This region has a mean annual precipitation of $1118.7 \mathrm{~mm}$ per year. The main soil type is classified as yellow-brown soil with soil thickness ranging from 30 to $60 \mathrm{~cm}$ (Yan et al. 2014). The studied forest is considered as a 50-year-old secondary forest. The most common tree species at the canopy layer are Quercus acutissima and Q. variabilis. Soil properties at the beginning of the experiment were described as the study in Li et al. (2018).

\section{Experimental design}

This experiment was performed in July 2013 with a complete randomized block design. Four treatments with four replications were set up. Each plot was $10 \mathrm{~m} \times$ $10 \mathrm{~m}$ and separated by a $10 \mathrm{~m}$-wide buffer strip. The treatments were implemented as follows: control (CK), $\mathrm{N}$ addition $\left(\mathrm{N}, 10 \mathrm{~g} \cdot \mathrm{m}^{-2} \cdot \mathrm{yr}^{-1} \mathrm{NH}_{4} \mathrm{NO}_{3}\right), \mathrm{P}$ addition (P, $10 \mathrm{~g} \cdot \mathrm{m}^{-2} \cdot \mathrm{yr}^{-1} \mathrm{NaH}_{2} \mathrm{PO}_{4}$ ), and $\mathrm{N}$ and $\mathrm{P}$ co-addition (NP, $10 \mathrm{~g} \cdot \mathrm{m}^{-2} \cdot \mathrm{yr}^{-1} \mathrm{NH}_{4} \mathrm{NO}_{3}$ plus $\left.10 \mathrm{~g} \cdot \mathrm{m}^{-2} \cdot \mathrm{yr}^{-1} \mathrm{NaH}_{2} \mathrm{PO}_{4}\right)$. The fertilizer was dissolved in $50 \mathrm{~L}$ of water and sprayed using a portable sprayer. The same amount of water was employed in the control plots, equivalent to an annual precipitation increase of $0.5 \mathrm{~mm}$ each year. $\mathrm{N}$ and $\mathrm{P}$ supplies were conducted monthly from May to October during the growing season in each year.

\section{Soil respiration and its autotrophic and heterotrophic components}

For soil total respiration $\left(R_{\mathrm{s}}\right)$ measurements, three polyvinyl chloride (PVC) collars $(20 \mathrm{~cm}$ in diameter and 8 $\mathrm{cm}$ in height) were inserted into $5 \mathrm{~cm}$ depth in each plot. The trenching method was used to separate autotropic respiration $\left(R_{\mathrm{a}}\right)$ and heterotrophic respiration $\left(R_{\mathrm{h}}\right)$ from $R_{\mathrm{s}}$. Specifically, one subplot $(1 \mathrm{~m} \times 1 \mathrm{~m})$ was set and trenched to $60 \mathrm{~cm}$ depth in each plot in July 2013. The polyethylene boards were installed inside the trenches to avoid root regrowth into the subplots. Living plants were cut to keep the trenched subplots free of roots with the minimum disturbance to the soil. Three PVC collars were also established in each trenched subplot. Because the respiration in the trenched subplots was originated only from microbes but not from roots, it refers to $R_{\mathrm{h}}$. $R_{\mathrm{a}}$ was calculated by subtracting $R_{\mathrm{h}}$ from $R_{\mathrm{s}}$. $R_{\mathrm{s}}$ and its components were measured once a month from May to October during the study period. The Li-8100 automatic soil $\mathrm{CO}_{2}$ flux system (LI-COR Biosciences, Lincoln, Nebraska, USA) was used to measure soil respiration rates between 9:00 and 11:00 of the local time. Soil temperature and moisture at $5 \mathrm{~cm}$ depth were measured synchronously with monitoring of soil $\mathrm{CO}_{2}$ fluxes. In order to reduce the effect of dead root decomposition in the trenched plots, $R_{\mathrm{s}}$ and its components were initially measured in May 2014, nearly 1 year after the trenching implementation.

\section{Soil measurements}

\section{Soil chemical measurements and fine root biomass}

We collected soil samples in October 2014 and 2015. At each sampling plot, five $0-15 \mathrm{~cm}$ soil samples $(3.75 \mathrm{~cm}$ in diameter) were collected randomly after removing the litters. These five soil cores were combined to one composite sample and passed through a 2-mm mesh sieve immediately. Soil dissolved organic carbon (DOC), ammonium nitrogen $\left(\mathrm{NH}_{4}{ }^{+}-\mathrm{N}\right)$, nitrate nitrogen $\left(\mathrm{NO}_{3}{ }^{-}-\mathrm{N}\right)$, and microbial biomass carbon (MBC) contents were measured with fresh soils from one part of soil samples. The other part of soil samples was air-dried, crushed, and then sieved for soil available phosphorus (AP), extractable cations $\left(\mathrm{Al}^{3+}, \mathrm{Ca}^{2+}, \mathrm{Mg}^{2+}\right.$, and $\left.\mathrm{Na}^{+}\right)$and $\mathrm{pH}$ measurements. For soil DOC measurement, fresh soil sample was extracted with $0.5 \mathrm{M} \mathrm{K}_{2} \mathrm{SO}_{4}$ and the extracts in filtered through a $0.45 \mu \mathrm{m}$ cellulose acetate filter (Millipore) were analyzed with a TOC analyzer (multi N/C 3100, Analytik Jena, Germany). Soil inorganic N concentrations $\left(\mathrm{NH}_{4}{ }^{+}-\mathrm{N}, \mathrm{NO}_{3}{ }^{-}-\mathrm{N}\right)$ were determined after extraction using $2 \mathrm{M} \mathrm{KCl}$ solution on a FIAstar 
5000 Analyzer (Foss Tecator, Denmark). Soil available phosphorus was measured with a spectrophotometer (UV2550, Shimadzu, Japan). The extractable cations were measured according to the method in Mao et al. (2017). Soil pH was measured with a ratio of 1:2.5 (soil: water solution). Soil MBC was determined by the method of chloroform fumigation extraction (Liu et al. 2009). Fine root biomass was determined in November 2014 and 2015 with an auger $(10 \mathrm{~cm}$ diameter, $15 \mathrm{~cm}$ deep). The roots were collected from soil cores through a $1-\mathrm{mm}$ mesh sieve, dried for $48 \mathrm{~h}$ at $65^{\circ} \mathrm{C}$ to a constant weight and measured to estimate fine root biomass.

\section{Microbial community composition}

Soil microbial community composition was measured by phospholipid fatty acids (PLFAs) analysis following the method from Bossio et al. (1998). The fatty acids were analyzed with the Agilent 6890 (Agilent Technologies, Palo Alto, CA, USA) and the MIDI Sherlock Microbial Identification System (MIDI Inc., Newark, DE, USA). Phospholipid fatty acids concentrations were determined based on the internal standard (19:0 nonadecanoic methyl ester). The PLFAs of i14:0, i15:0, a15:0, i16:0, 10Me 16:0,

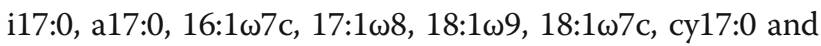

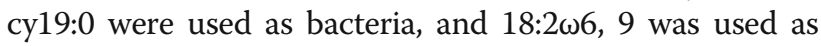
fungi. The 10Me 16:0, 10Me 17:0, and 10Me 18:0 were used as actinobacteria (Frostegård and Bååth 1996).

\section{Soil enzyme activity}

We measured four cellulose degrading enzymes activities, including $\alpha$-Glucosidase (AG), $\beta$-Glucosidase (BG), $\beta$-D-Cellubiosidase (CB), and $\beta$-Xylosidase (XYL) activity following the method proposed by Jing et al. (2016) and $\mathrm{Li}$ et al. (2018). In brief, approximately $1 \mathrm{~g}$ of homogenized fresh soil was slurried in $250 \mathrm{~mL}$ of $50 \mathrm{mM}$, pH 5 acetate buffer in blender for $2 \mathrm{~min}$. Soil slurries of $800 \mu \mathrm{L}$ was pipetted into 96-well microplate, and $200 \mu \mathrm{L}$ of $200 \mu \mathrm{M}$ substrate (4-methylumbelliferyl, MUB) was added to each assay. Six analytical replicates were used for each soil sample. The microplates were incubated at $25^{\circ} \mathrm{C}$ for $3 \mathrm{~h}$ in the dark. The fluorescence was determined with a SynergyMX microplate reader (Biotek, VT, USA) at $365 \mathrm{~nm}$ for excitation and $450 \mathrm{~nm}$ for emission. The enzyme activity was expressed as nmol.g dry weight ${ }^{-1} \cdot \mathrm{h}^{-1}$.

\section{Statistical analysis}

The relationships between soil respiration rates and soil temperature were fitted with the following equation, $R=$ $a \mathrm{e}^{b T}$. In this equation, $R$ is soil respiration rate $\left(\mu \mathrm{mol} \cdot \mathrm{m}^{-2}\right.$. $\left.\mathrm{s}^{-1}\right), T$ is soil temperature at $5 \mathrm{~cm}$ depth $\left({ }^{\circ} \mathrm{C}\right)$. With reference to previous studies (Zou et al. 2018; Liu et al. 2019; Wei et al. 2020), the temperature sensitivity $\left(Q_{10}\right)$ of soil respiration rates was calculated as $Q_{10}=\mathrm{e}^{10 b}$. Repeatedmeasured ANOVA tests were used to examine the treatment effect on the rates of $R_{\mathrm{s}}, R_{\mathrm{h}}$ and $R_{\mathrm{a}}$ in 2014 and 2015. Two-way ANOVA was performed to investigate the effects of $\mathrm{N}$ addition, $\mathrm{P}$ addition, and their interaction on the mean $R_{\mathrm{s}}$ and its components, soil enzymes activity, microbial community composition, as well as soil characteristics during the growing season in 2014 and 2015. One-way ANOVA with Tukey's HSD was used to test the differences among treatments in the fine root biomass, soil properties, $\mathrm{MBC}$, and DOC, as well as the average values of $R_{\mathrm{s}}, R_{\mathrm{h}}$, and $R_{\mathrm{a}} \cdot R_{\mathrm{a}}$ and $R_{\mathrm{h}}$ in relation to abiotic and biotic controlling factors were further examined using linear regression models. A random forest algorithm was finally applied to assess the relative importance of abiotic and biotic drivers on $R_{\mathrm{a}}$ and $R_{\mathrm{h}}$ (Wang et al. 2019b). This method does not need any distribution assumptions and can deal with nonnormal data and nonlinear relationships in the dataset. The importance values of each controlling factors were assessed by running the random forest 100 times (van Elsas et al. 2012). The normality and homogeneity tests of the data were performed before analyses and were transformed if the assumptions were not met. Statistical analyses were conducted with SPSS 19.0 (SPSS Inc., Chicago, IL, USA) for windows. The significance throughout the analyses was set at $P<0.05$.

\section{Results}

Soil chemical properties and fine root biomass

Soil temperature and moisture showed clear seasonal variations and were not responsive to $\mathrm{N}$ and/or $\mathrm{P}$ addition (Fig. S1). Soil dissolved organic carbon (DOC) was not changed by any treatment in $2014(P>0.05)$, but it was significantly increased by $7.2 \%$ under $\mathrm{P}$ addition and by 10.0\% under NP addition in 2015 compared with the control (Table 1, Table S1). Soil microbial biomass carbon $(\mathrm{MBC})$ was not significantly affected by $\mathrm{N}, \mathrm{P}$ or NP addition in either year $(P>0.05)$. Soil $\mathrm{NH}_{4}{ }^{+}-\mathrm{N}$ was increased by $35.0 \%$ under $\mathrm{N}$ addition in 2014 and decreased by $13.0 \%$ under $P$ addition in $2015(P<0.05)$. Nitrogen addition increased soil $\mathrm{NO}_{3}{ }^{-}-\mathrm{N}$ by $10 \%-18 \%$ across 2 years, while $\mathrm{P}$ addition decreased it by $8.9 \%$ in 2014 (all $P<0.05)$. Nitrogen addition did not significantly change soil AP, which was on average increased by 3.8 to 4.4 times, 3.5 to 4.5 times across 2 years under $\mathrm{P}$ and NP addition, respectively (all $P<0.05$ ). Soil $\mathrm{pH}$ was not altered by any treatment in 2014, however, it was significantly decreased by $0.4,0.2$ and 0.3 unit under $\mathrm{N}, \mathrm{P}$ and NP addition, respectively in 2015 (Table 1). Compared to the control conditions, soil $\mathrm{Al}^{3+}$ was increased under $\mathrm{N}, \mathrm{P}$, and NP treatments, while $\mathrm{Ca}^{2+}$ was decreased significantly under $\mathrm{N}$ and NP treatments (all $P<0.05$ ). N, P, and NP treatments did not change the concentrations of $\mathrm{Mg}^{2+}$ or $\mathrm{Na}^{+}(P>0.05)$. Fine root biomass was reduced by $17.3 \%$, $8.4 \%$, and $14.3 \%$ under N, P, and NP addition, respectively across 2 years (all $P<0.05$, Table 1 ). 
Table 1 Soil available carbon, nitrogen, and phosphorus, soil cations, as well as fine root biomass under different treatments

\begin{tabular}{|c|c|c|c|c|c|}
\hline & Year & CK & $\mathbf{N}$ & $\mathbf{P}$ & NP \\
\hline \multicolumn{6}{|l|}{ Available C\&N\&P } \\
\hline \multirow[t]{2}{*}{$\mathrm{DOC}\left(\mathrm{mg} \cdot \mathrm{kg}^{-1}\right)$} & 2014 & $299.2 \pm 8.3 \mathrm{a}$ & $281.6 \pm 6.1 \mathrm{a}$ & $310.4 \pm 19.1 \mathrm{a}$ & $314.1 \pm 28.3 a$ \\
\hline & 2015 & $294.8 \pm 2.8 b$ & $288.9 \pm 5.5 b$ & $316.0 \pm 3.1 \mathrm{a}$ & $324.3 \pm 5.3 a$ \\
\hline \multirow[t]{2}{*}{$\mathrm{MBC}\left(\mathrm{mg} \cdot \mathrm{kg}^{-1}\right)$} & 2014 & $571.7 \pm 3.8 \mathrm{a}$ & $557.1 \pm 3.5 a$ & $589.3 \pm 2.9 \mathrm{a}$ & $588.2 \pm 19.6 \mathrm{a}$ \\
\hline & 2015 & $563.4 \pm 15 a b$ & $545 \pm 10.3 b$ & $593.2 \pm 4.8 \mathrm{a}$ & $587.0 \pm 1.7 \mathrm{a}$ \\
\hline \multirow[t]{2}{*}{$\mathrm{NH}_{4}^{+}\left(\mathrm{mg} \cdot \mathrm{kg}^{-1}\right)$} & 2014 & $8.1 \pm 0.2 b$ & $10.9 \pm 0.6 \mathrm{a}$ & $6.8 \pm 0.1 b$ & $7.4 \pm 0.5 b$ \\
\hline & 2015 & $7.7 \pm 0.1 \mathrm{a}$ & $8.7 \pm 0.6 \mathrm{a}$ & $6.7 \pm 0.1 b$ & $8.1 \pm 0.03 a$ \\
\hline \multirow[t]{2}{*}{$\mathrm{NO}_{3}^{-}\left(\mathrm{mg} \cdot \mathrm{kg}^{-1}\right)$} & 2014 & $38.4 \pm 0.9 b$ & $42.4 \pm 1.1 \mathrm{a}$ & $35.0 \pm 0.3 c$ & $37.1 \pm 0.9 b c$ \\
\hline & 2015 & $40.6 \pm 0.1 b$ & $48.1 \pm 2.3 \mathrm{a}$ & $36.9 \pm 0.3 b$ & $41.6 \pm 0.7 b$ \\
\hline \multirow[t]{2}{*}{ AP $\left(\mathrm{mg} \cdot \mathrm{kg}^{-1}\right)$} & 2014 & $27.5 \pm 8.4 b$ & $24.8 \pm 4.3 b$ & $149.3 \pm 11.9 \mathrm{a}$ & $150.6 \pm 21.4 a$ \\
\hline & 2015 & $29.3 \pm 3.6 b$ & $22.3 \pm 4.1 \mathrm{~b}$ & $139.4 \pm 12.8 \mathrm{a}$ & $131.9 \pm 9.8 \mathrm{a}$ \\
\hline \multicolumn{6}{|l|}{ Soil cations } \\
\hline \multirow[t]{2}{*}{ Soil pH } & 2014 & $4.7 \pm 0.04 \mathrm{a}$ & $4.5 \pm 0.07 a$ & $4.6 \pm 0.03 a$ & $4.5 \pm 0.1 \mathrm{a}$ \\
\hline & 2015 & $4.6 \pm 0.08 \mathrm{a}$ & $4.2 \pm 0.04 b$ & $4.4 \pm 0.1 b$ & $4.3 \pm 0.01 b$ \\
\hline \multirow[t]{2}{*}{$\mathrm{Al}^{3+}\left(\mathrm{mmol} \cdot \mathrm{kg}^{-1}\right)$} & 2014 & $38.0 \pm 1.0 \mathrm{C}$ & $50.2 \pm 1.0 \mathrm{a}$ & $42.4 \pm 0.8 b$ & $44.8 \pm 0.9 b$ \\
\hline & 2015 & $38.4 \pm 3.2 c$ & $60.4 \pm 0.4 a$ & $48.7 \pm 0.8 b$ & $61.0 \pm 1.4 \mathrm{a}$ \\
\hline \multirow[t]{2}{*}{$\mathrm{Ca}^{2+}\left(\mathrm{mmol} \cdot \mathrm{kg}^{-1}\right)$} & 2014 & $33.6 \pm 3.1 \mathrm{a}$ & $25.1 \pm 1.8 b$ & $28.8 \pm 0.3 \mathrm{ab}$ & $25.0 \pm 0.7 b$ \\
\hline & 2015 & $30.3 \pm 2.9 a$ & $20.1 \pm 0.5 c$ & $26.0 \pm 0.2 \mathrm{ab}$ & $22.6 \pm 0.5 b c$ \\
\hline \multirow[t]{2}{*}{$\mathrm{Mg}^{2+}\left(\mathrm{mmol} \cdot \mathrm{kg}^{-1}\right)$} & 2014 & $4.7 \pm 0.4 \mathrm{a}$ & $4.3 \pm 0.2 \mathrm{a}$ & $4.2 \pm 0.4 \mathrm{a}$ & $4.2 \pm 0.1 \mathrm{a}$ \\
\hline & 2015 & $4.2 \pm 1.0 \mathrm{a}$ & $3.5 \pm 0.6 \mathrm{a}$ & $3.7 \pm 0.1 \mathrm{a}$ & $3.3 \pm 0.1 \mathrm{a}$ \\
\hline \multirow[t]{2}{*}{$\mathrm{Na}^{2+}\left(\mathrm{mmol} \cdot \mathrm{kg}^{-1}\right)$} & 2014 & $1.5 \pm 0.2 \mathrm{a}$ & $1.4 \pm 0.04 a$ & $1.3 \pm 0.3 \mathrm{a}$ & $1.3 \pm 0.2 \mathrm{a}$ \\
\hline & 2015 & $1.2 \pm 0.2 \mathrm{a}$ & $1.3 \pm 0.4 \mathrm{a}$ & $1.2 \pm 0.1 \mathrm{a}$ & $1.2 \pm 0.1 \mathrm{a}$ \\
\hline \multicolumn{6}{|l|}{ Plant } \\
\hline \multirow[t]{2}{*}{ Fine root biomass $\left(\mathrm{g} \cdot \mathrm{m}^{-2}\right)$} & 2014 & $172.2 \pm 1.3 \mathrm{a}$ & $147.4 \pm 4.0 \mathrm{C}$ & $161.9 \pm 0.7 \mathrm{~b}$ & $152.2 \pm 1.5 c$ \\
\hline & 2015 & $178.9 \pm 1.9 \mathrm{a}$ & $142.6 \pm 1.7 d$ & $159.7 \pm 1.4 \mathrm{~b}$ & $148.6 \pm 1.2 c$ \\
\hline
\end{tabular}

Notes: Values are means with SE. The different lowercase letters in the same row indicate significant differences among the four treatments at $P<0.05$ level. $\mathrm{CK}$, control; N, nitrogen addition; P, phosphorus addition; NP, nitrogen and phosphorus addition

\section{Soil respiration and its components}

Soil respiration and its components exhibited strong seasonal patterns in both 2014 and 2015, with high values in July and August (Fig. 1). N or P addition significantly affected $R_{\mathrm{s}}, R_{\mathrm{h}}$ and $R_{\mathrm{a}}$ in $2014(P<0.01)$, with the exception of $R_{\mathrm{h}}$ under $\mathrm{N}$ addition ( $P>0.05$, Table 2$)$. However, there were no significant changes in $R_{\mathrm{s}}, R_{\mathrm{h}}$ or $R_{\mathrm{a}}$ under $\mathrm{N}$ or $\mathrm{P}$ addition in $2015(P>0.05$, Table 2$) . R_{\mathrm{s}}$ and its components were significantly affected by the interaction of $\mathrm{N}$ addition and $\mathrm{P}$ addition in both 2014 and 2015 $(P<0.01)$. Mean $R_{\mathrm{s}}$ and $R_{\mathrm{h}}$ under $\mathrm{N}$ addition were reduced by $15.2 \%$ and $11.7 \%$, respectively, and mean $R_{\mathrm{a}}$ was decreased by $15.0 \%$ relative to the control across the 2 years. $\mathrm{P}$ addition had an inconsistent effect on $R_{\mathrm{a}}$, with $R_{\mathrm{a}}$ increasing by $50.5 \%$ in 2014 and decreasing by $26.6 \%$ in 2015. Moreover, $\mathrm{P}$ addition on average decreased the mean $R_{\mathrm{s}}$ and $R_{\mathrm{h}}$ by $11.1 \%$ and $19.9 \%$, respectively during the experimental period (Fig. 1). NP addition on average increased $R_{\mathrm{s}}, R_{\mathrm{a}}$, and $R_{\mathrm{h}}$ by $1.9 \%, 7.9 \%$, and $2.1 \%$, respectively $(P>0.05)$ across 2 years. There were significant correlations between soil respiration rates and soil temperature (Fig. S2). N and/or P addition did not alter $Q_{10}$ values of $R_{\mathrm{s}}(P>0.05)$. The $Q_{10}$ values of $R_{\mathrm{h}}$ were significantly decreased under $\mathrm{P}$ and NP addition in 2014 $(P<0.05)$, but did not change by any treatment in 2015 $(P>0.05$, Table 3$)$.

\section{Soil microbial community composition and enzyme activities}

Compared to the control, $\mathrm{N}$ addition, $\mathrm{P}$ addition, and NP addition did not affect bacterial, actinobacterial, fungal PLFA and fungi: bacterial ratio in 2014 (all $P>0.05$ ) (Fig. 2a-d), whereas the bacterial PLFA was significantly increased by $29.4 \%(P<0.05)$ under NP addition in 2015 (Fig. 2e). Meanwhile, $\mathrm{P}$ addition increased fungal PLFA by $23.5 \%(P<0.05)$, but fungi: bacterial ratio was not affected by any treatments in $2015(P>0.05)$ (Figs. $2 \mathrm{~g}-\mathrm{h}$ ). Soil $\alpha$-Glucosidase (AG) activity did not change significantly under any treatment in either years $(P>0.05)$ (Fig. 3a, e), whereas $P$ addition significantly enhanced $\beta$ - 

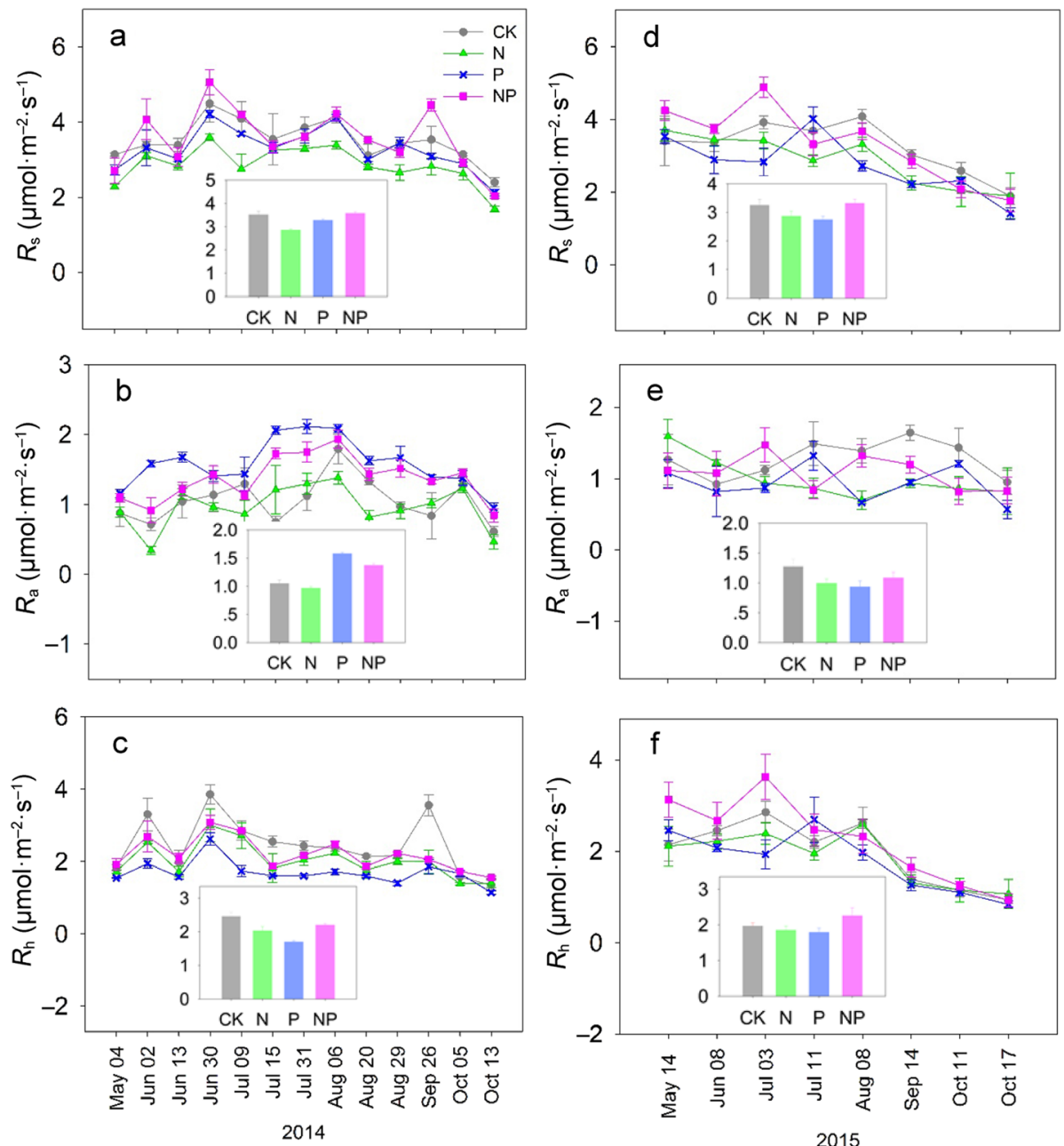

Fig. 1 Seasonal variability of soil respiration $\left(R_{\mathrm{s}}\right)$, autotrophic respiration $\left(R_{\mathrm{a}}\right)$ and heterotrophic respiration $\left(R_{\mathrm{h}}\right)$ under four treatments from 2014 to 2015. Vertical bars show standard errors of the means $(n=4)$. CK, control; N, nitrogen addition; $\mathrm{P}$, phosphorus addition; NP, both nitrogen and phosphorus addition

Glucosidase (BG) activity in $2014(P<0.05)$ (Fig. 3b). Neither N nor P addition changed BG activity in 2015 (Fig. 3f). $\beta$-D-Cellubiosidase (CB) and $\beta$-Xylosidase (XYL) activity were significantly decreased under $\mathrm{N}$ addition and affected by the interaction of $\mathrm{N}$ and $\mathrm{P}$ addition in 2014 (Fig. 3c, d), while the significant treatment effect was only found for the interaction of $\mathrm{N}$ and $P$ addition in $2015(P<0.001)$ (Fig. 3g, h).

\section{Controlling factors of $R_{\mathrm{s}}$ and its components}

$R_{\mathrm{a}}$ was negatively correlated with soil $\mathrm{Al}^{3+}(P<0.05)$, $\mathrm{NH}_{4}{ }^{+}-\mathrm{N}$ and $\mathrm{NO}_{3}{ }^{-}-\mathrm{N}(P<0.001)$, but positively related with DOC $(P<0.05), \mathrm{XYL}$ and $\mathrm{CB}$ activities $(P<0.001)$ (Fig. 4). $R_{\mathrm{h}}$ was positively related to bacteria PLFA, Fungi PLFA, CB and XYL activities $(P<0.01)$. The random forest also showed that $R_{\mathrm{a}}$ was mainly controlled by XYL activity, followed by $\mathrm{NO}_{3}{ }^{-}-\mathrm{N}, \mathrm{CB}$ activity, $\mathrm{Al}^{3+}, \mathrm{DOC}$, and $\mathrm{NH}_{4}{ }^{+}-\mathrm{N}$ (Fig. 5). However, the variation in $R_{\mathrm{h}}$ was primarily regulated by bacterial PLFA and CB activity, followed by fungal PLFA and XYL activity. Overall, $R_{\mathrm{S}}$ had significantly positive correlations with fungal PLFA, $\mathrm{XYL}$ and $\mathrm{CB}$ activities (Fig. S3). In addition, $R_{\mathrm{s}}$ increased significantly with soil MBC $(P<0.05)$ (Table S2).

\section{Discussion}

Contrasting responses of $R_{\mathrm{s}}$ to nitrogen and phosphorus addition

We found that $\mathrm{N}$ or $\mathrm{P}$ addition alone decreased $R_{\mathrm{s}}$, while $\mathrm{NP}$ addition increased $R_{\mathrm{s}}$ during the 2-year field observation in this subtropical forest. This implies that soil respiration may be co-limited by $\mathrm{N}$ and $\mathrm{P}$ corroborating a previous study conducted in subtropical area (Wei et al. 2020). Both $\mathrm{N}$ and $\mathrm{P}$ addition alone inhibited $R_{\mathrm{s}}$, which is in accordance with most of the previous studies in 
Table 2 Results (F-values) of repeated-measures ANOVAs exploring the effects of measurement date (day) or year, nitrogen addition $(N)$, phosphorus addition $(P)$ and their interactions on soil respiration $\left(R_{\mathrm{s}}\right)$ and its components $\left(R_{\mathrm{a}}\right.$ and $\left.R_{\mathrm{h}}\right)(n=4)$

\begin{tabular}{lllll}
\hline Year & Factor & $\boldsymbol{R}_{\mathbf{s}}$ & $\boldsymbol{R}_{\mathbf{a}}$ & $\boldsymbol{R}_{\mathbf{h}}$ \\
\hline 2014 & Day & $25.26^{* * *}$ & $16.59^{* * *}$ & $22.73^{* * *}$ \\
& $\mathrm{~N}$ & $8.02^{* *}$ & $16.16^{* * *}$ & 0.96 \\
& $\mathrm{P}$ & $14.28^{* * *}$ & $147.78^{* * *}$ & $33.56^{* * *}$ \\
& $\mathrm{~N} \times \mathrm{P}$ & $55.70^{* * *}$ & 2.43 & $81.09^{* * *}$ \\
& Day $\times \mathrm{N}$ & 1.37 & 1.70 & $2.44^{* *}$ \\
& Day $\times \mathrm{P}$ & 1.24 & $2.74^{* *}$ & $2.63^{* *}$ \\
& Day $\times \mathrm{N} \times \mathrm{P}$ & 1.53 & 1.61 & 1.74 \\
& Day & $26.44^{* * *}$ & 2.06 & $26.33^{* * *}$ \\
& $\mathrm{~N}$ & 0.89 & 0.97 & 3.45 \\
& $\mathrm{P}$ & 0.06 & 3.26 & 1.54 \\
& $\mathrm{~N} \times \mathrm{P}$ & $21.39^{* * *}$ & $9.97^{* *}$ & $9.63^{* *}$ \\
& Day $\times \mathrm{N}$ & $2.94^{* *}$ & $2.68^{*}$ & 0.82 \\
& Day $\times \mathrm{P}$ & 1.11 & 0.52 & 1.74 \\
& Day $\times \mathrm{N} \times \mathrm{P}$ & $2.12^{*}$ & 2.02 & 1.80 \\
\hline
\end{tabular}

${ }^{*} P<0.05,{ }^{* *} P<0.01,{ }^{* * *} P<0.001$

other forest ecosystems (Peng et al. 2017a; Li et al. 2018; Xiao et al. 2020; Zhang et al. 2020). It has been shown that the reduction of $R_{\mathrm{s}}$ was mainly due to the negative responses of $R_{\mathrm{h}}$ to fertilizer addition (Fig. 1). The positive effect of NP addition on $R_{\mathrm{s}}$ could be due to that soil labile $\mathrm{C}$ and microbial activities may be accelerated by $\mathrm{P}$ addition, which will cause the different impacts on soil microbial community and enzyme activities with $\mathrm{N}$ and $\mathrm{P}$ addition synchronously (Liu et al. 2019). This study demonstrated that the stimulation of fungal PLFA, CB and XYL activities induced by $\mathrm{N}$ and $\mathrm{P}$ addition in combination exceeded the inhibitory effects of $\mathrm{N}$ or $\mathrm{P}$ addition alone, accounting for the increased $R_{\mathrm{s}}$ under

Table 3 The $Q_{10}$ values of soil total respiration $\left(R_{\mathrm{s}}\right)$ and heterotrophic respiration $\left(R_{h}\right)$

\begin{tabular}{llll}
\hline Year & Treatments & $\boldsymbol{R}_{\mathbf{s}}$ & $\boldsymbol{R}_{\mathbf{h}}$ \\
\hline 2014 & CK & $1.31 \pm 0.07 \mathrm{a}$ & $1.44 \pm 0.06 \mathrm{a}$ \\
& N & $1.44 \pm 0.10 \mathrm{a}$ & $1.41 \pm 0.13 \mathrm{a}$ \\
& P & $1.45 \pm 0.08 \mathrm{a}$ & $1.10 \pm 0.02 \mathrm{~b}$ \\
& NP & $1.48 \pm 0.12 \mathrm{a}$ & $1.31 \pm 0.10 \mathrm{ab}$ \\
& CK & $1.79 \pm 0.30 \mathrm{a}$ & $2.35 \pm 0.67 \mathrm{a}$ \\
& N & $1.68 \pm 0.31 \mathrm{a}$ & $2.47 \pm 0.54 \mathrm{a}$ \\
& P & $1.39 \pm 0.06 \mathrm{a}$ & $1.65 \pm 0.14 \mathrm{a}$ \\
& NP & $1.60 \pm 0.13 \mathrm{a}$ & $1.75 \pm 0.35 \mathrm{a}$ \\
\hline
\end{tabular}

Note: Different letters in the column represent significant differences among the four treatments at $P<0.05$ level
NP addition. In view of few studies on the interactive effect, the response of soil respiration to the interaction of $\mathrm{N}$ and $\mathrm{P}$ addition is critical to understand ecological dynamics in the forest management. Further work is still necessary to explore the potential mechanisms for $R_{\mathrm{s}}$ under $\mathrm{N}$ and $\mathrm{P}$ enrichment in combination ( $\mathrm{Li}$ et al. 2016).

\section{Differential responses of $R_{\mathrm{a}}$ and $R_{\mathrm{h}}$ to nitrogen and phosphorus addition}

We demonstrated that the two components of soil respiration $-R_{\mathrm{a}}$ and $R_{\mathrm{h}}$-responded differently to $\mathrm{N}$ and $\mathrm{P}$ addition. Nitrogen addition decreased $R_{\mathrm{a}}$ and $R_{\mathrm{h}}$ in our study in both years (Fig. 1). Previous studies have suggested that the reduction of $R_{\mathrm{a}}$ was closely related to the decrease in fine root biomass (Wang et al. 2015; Wang et al. 2017a; Liu et al. 2019). Although we detected a lower $R_{\mathrm{a}}$ accompanied with decreasing fine root biomass under $\mathrm{N}$ addition (Table 1 ), $R_{\mathrm{a}}$ had no significant correlation with fine root biomass (Fig. 5). The reduction of $R_{\mathrm{a}}$ could have resulted from soil acidification and ion imbalance by decreasing soil $\mathrm{pH}$ and base cations $\left(\mathrm{Ca}^{2+}\right.$, $\mathrm{Na}^{+}$and $\mathrm{Mg}^{2+}$ ) (Table 1). Meanwhile, increasing $\mathrm{Al} / \mathrm{Ca}$ ratios and decreasing base cations under excessive $\mathrm{N}$ addition indicate that the forest plants might be stressed by metal ion (Mao et al. 2017) and consequently affect $R_{\mathrm{a}}$. The inhibitory of $\mathrm{N}$ enrichment on $R_{\mathrm{h}}$ was closely associated with changes in soil microbial activity and enzymes (Fig. 5). The global meta-analysis and field experiments have suggested that excessive $\mathrm{N}$ inputs exhibit negative effects on soil microbes (Tian et al. 2017; Zhang et al. 2018). It has also revealed that increasing soil available nutrients can reduce the production of soil enzymes (Cusack et al. 2010) and impede the formation of soil microbial C (Widdig et al. 2020). Moreover, soil acidification with $\mathrm{N}$ addition can affect soil microbial communities, which is closely associated with soil microbial respiration ( $\mathrm{Li}$ et al. 2018). Hence, the lower soil $\mathrm{pH}$, changes in microbial community composition, and reducing soil enzymes may explain the decrease in soil $R_{\mathrm{h}}$ under $\mathrm{N}$ addition in this study.

We also found that $\mathrm{P}$ addition alone had inconsistent effects on $R_{\mathrm{a}}$ in this subtropical forest, with $R_{\mathrm{a}}$ increasing in the first year and decreasing in the following year. The contrasting response of $R_{\mathrm{a}}$ to $\mathrm{P}$ addition with time may be due to changes in the abiotic and biotic controlling factors. For example, soil $\mathrm{pH}$ was not altered by $\mathrm{P}$ addition in 2014, but was significantly reduced in 2015 suggesting a progressive soil acidification with experiment lengthens (Table 1). Similarly, soil $\mathrm{Al}^{3+}$ toxicity was more apparent in the second year than the initial stage of experiment. The varying responses of $R_{\mathrm{a}}$ to $\mathrm{P}$ addition alone suggest that long-term studies in the field are still imperative 

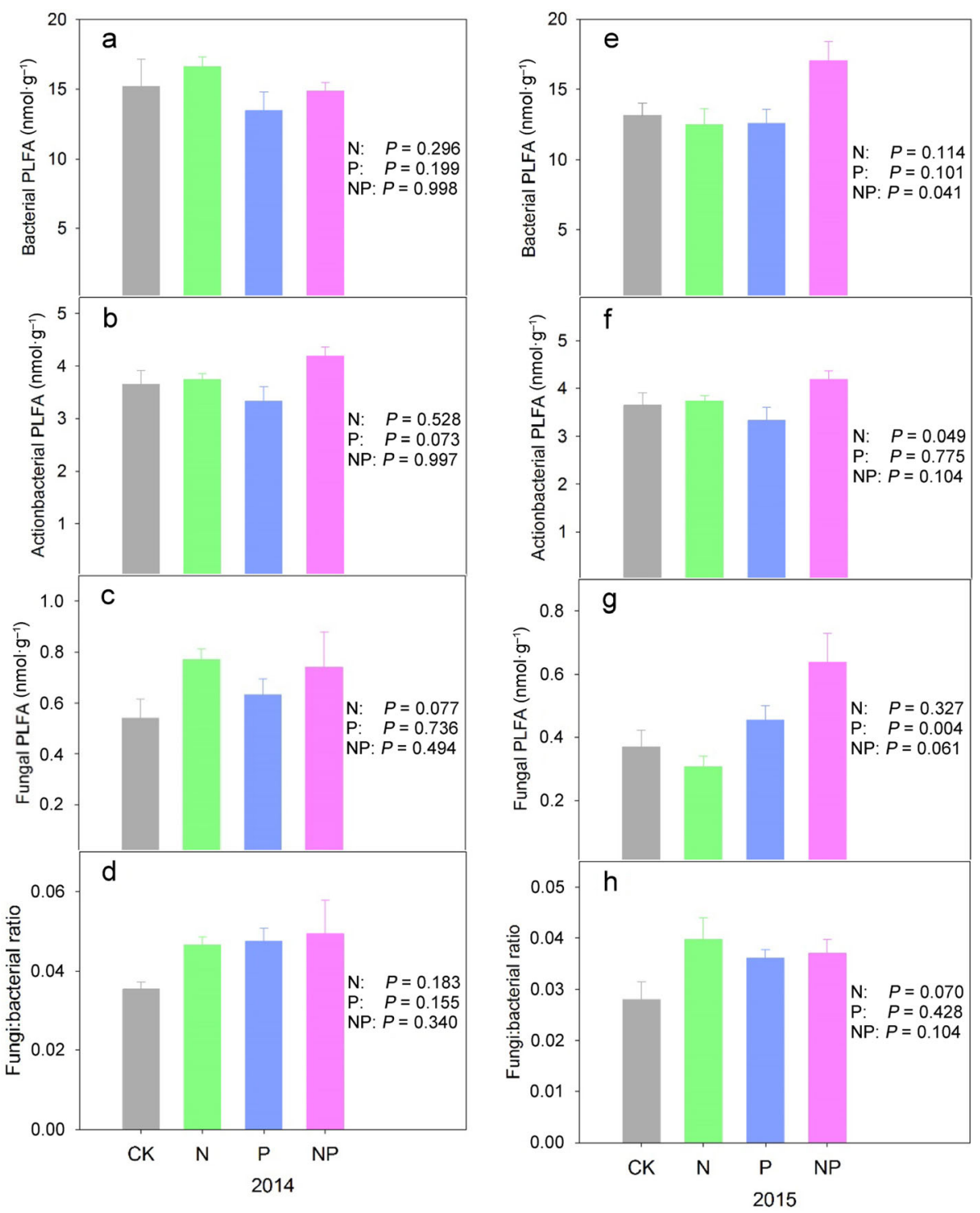

Fig. 2 Effects of nitrogen and phosphorus additions on soil microbial community in 2014 and 2015. Vertical bars represent the standard error of the mean $(n=4)$. CK, control; N, nitrogen addition; P, phosphorus addition; NP, both nitrogen and phosphorus addition. Two-way ANOVA shows the effects of $\mathrm{N}$ and $\mathrm{P}$ addition on soil microbial community

to assess the consequence of $\mathrm{P}$ addition on $R_{\mathrm{a}}$ in this P-limited ecosystem. $\mathrm{P}$ addition reduced $R_{\mathrm{h}}$ across 2 years, which is in accordance with a previous study in temperate forests (Zeng and Wang 2015). The reduction of $R_{\mathrm{h}}$ was also reflected by the decrease in soil enzyme activities, microbial PLFAs, and soil microbial biomass carbon (Jing et al. 2016). In this study, soil enzyme activities of CB and XYL were suppressed by $\mathrm{P}$ addition (Fig. 3, Table 1). Moreover, the significant positive correlations between $R_{\mathrm{h}}$ and PLFAs of fungi and bacteria suggested that the microbial community composition may also cause the change in soil $R_{\mathrm{h}}$ under P addition (Guo et al. 2017).
Contrary to the negative or inconsistent effects of $\mathrm{N}$ addition or $\mathrm{P}$ addition on $R_{\mathrm{a}}$ and $R_{\mathrm{h}}$, we found $\mathrm{NP}$ addition increased soil respiration components in the present study. To data, few efforts have been made to investigate the interaction of $\mathrm{N}$ and $\mathrm{P}$ addition on $R_{\mathrm{a}}$ and $R_{\mathrm{h}}$. In line with our findings, a combination of $\mathrm{N}$ and $\mathrm{P}$ addition experiment in $\mathrm{N}$-limited temperate forests also found an increase in $R_{\mathrm{a}}$ with $\mathrm{N}$ and $\mathrm{P}$ addition in combination (Zeng et al. 2018). Furthermore, the stimulation of $R_{\mathrm{h}}$ under NP addition has been reported in another subtropical forest (Liu et al. 2019). The stimulatory effect of $\mathrm{N}$ and $\mathrm{P}$ co-addition on $R_{\mathrm{h}}$ could be attributed to an increase in fungi/bacteria ratio under nutrient 

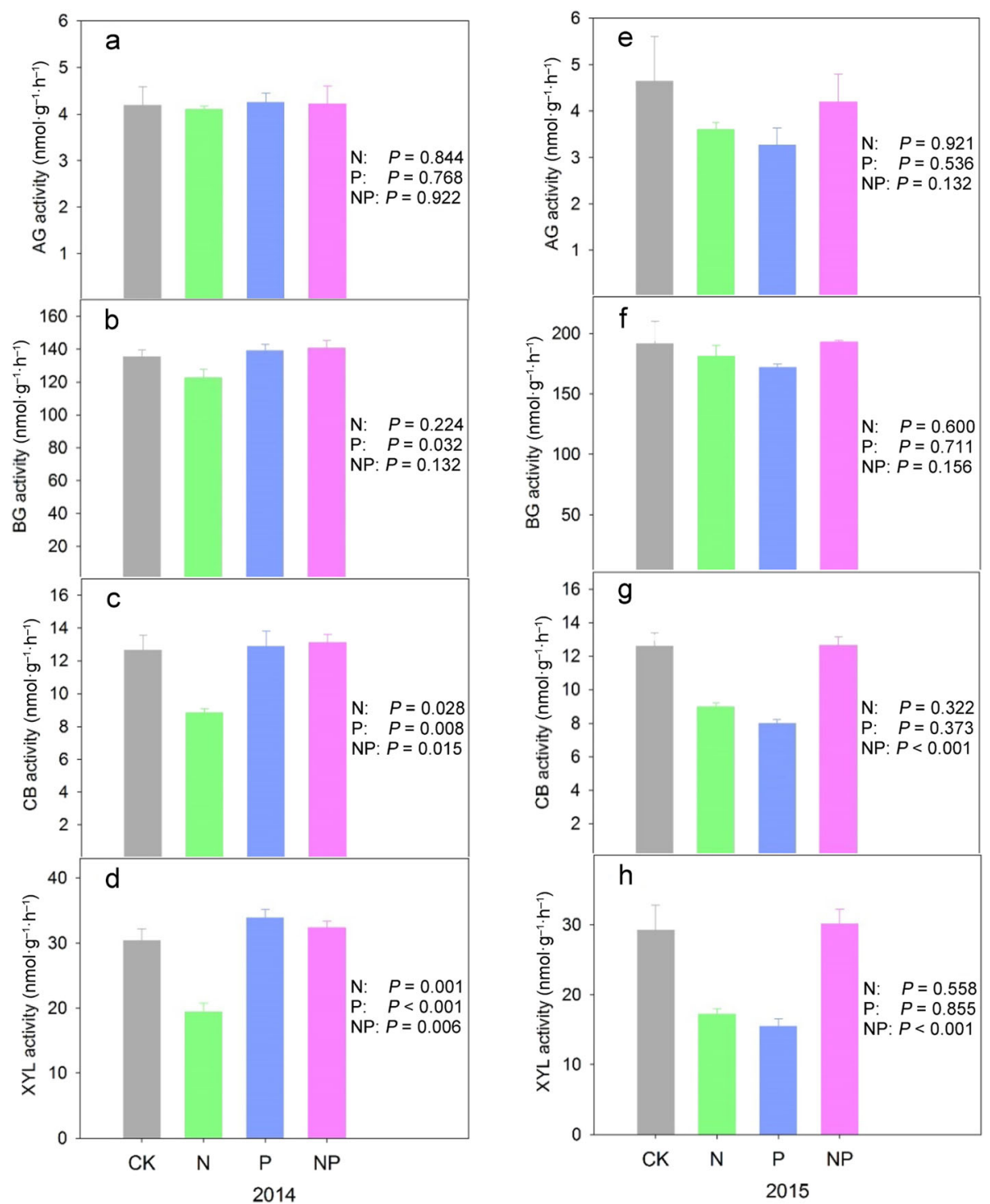

Fig. 3 Effects of nitrogen and phosphorus additions on soil enzyme activity in 2014 and 2015. Vertical bars represent the standard error of the mean $(n=4)$. CK, control; N, nitrogen addition; P, phosphorus addition; NP, both nitrogen and phosphorus addition. Two-way ANOVA shows the effects of $\mathrm{N}$ and $\mathrm{P}$ addition on soil enzymes activity

enrichment (Fig. 2), which might facilitate soil microbial carbon use efficiency (Riggs and Hobbie 2016). The increase of fungi/bacteria ratio in NP addition was also found in several other studies (Hagerberg et al. 2003; Liu et al. 2012; Zeng and Wang 2015). These results indicate that shifts in microbial community composition may play a vital role in regulating $R_{\mathrm{h}}$ changes following nutrient additions (Edwards et al. 2011). Accordingly, considering the interaction of $\mathrm{N}$ addition and $\mathrm{P}$ addition is necessary to evaluate responses of soil $\mathrm{C}$ processes in the scenario of aggravated $\mathrm{N}$ and $\mathrm{P}$ deposition. Our findings have additional implications for prediction of the impacts of $\mathrm{N}$ and $\mathrm{P}$ enrichment on soil $\mathrm{C}$ dynamics in subtropical forests.

\section{Responses of $Q_{10}$ to nitrogen and phosphorus addition}

Soil temperature is considered as one of the most important factors in regulating the changes of $R_{\mathrm{s}}$ (Zou et al. 2018). We found that $Q_{10}$ values of $R_{\mathrm{s}}$ and $R_{\mathrm{h}}$ were not affected by fertilization with the exception of $P$ addition significantly reducing $Q_{10}$ of $R_{\mathrm{h}}$ in 2014. Similarly, Wei et al. (2020) also found that $\mathrm{N}$ and/or $\mathrm{P}$ addition did not significantly alter $Q_{10}$ of $R_{\mathrm{s}}$ in a subtropical evergreen broad-leaved forest. The nonresponsiveness of temperature sensitivity of soil respiration 

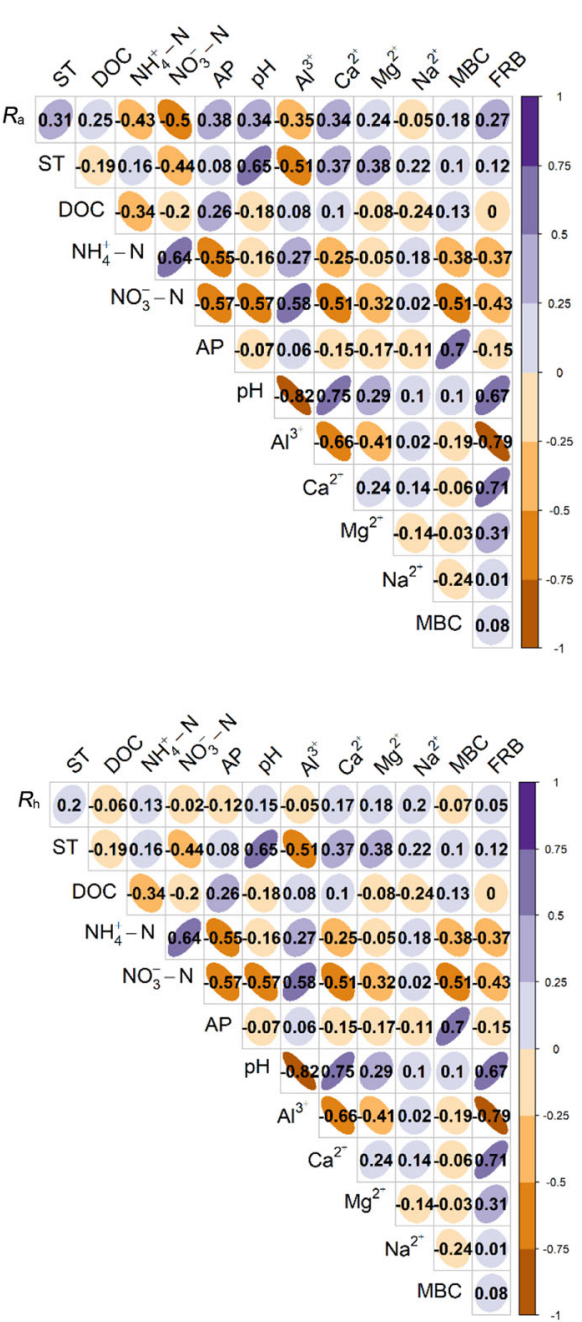
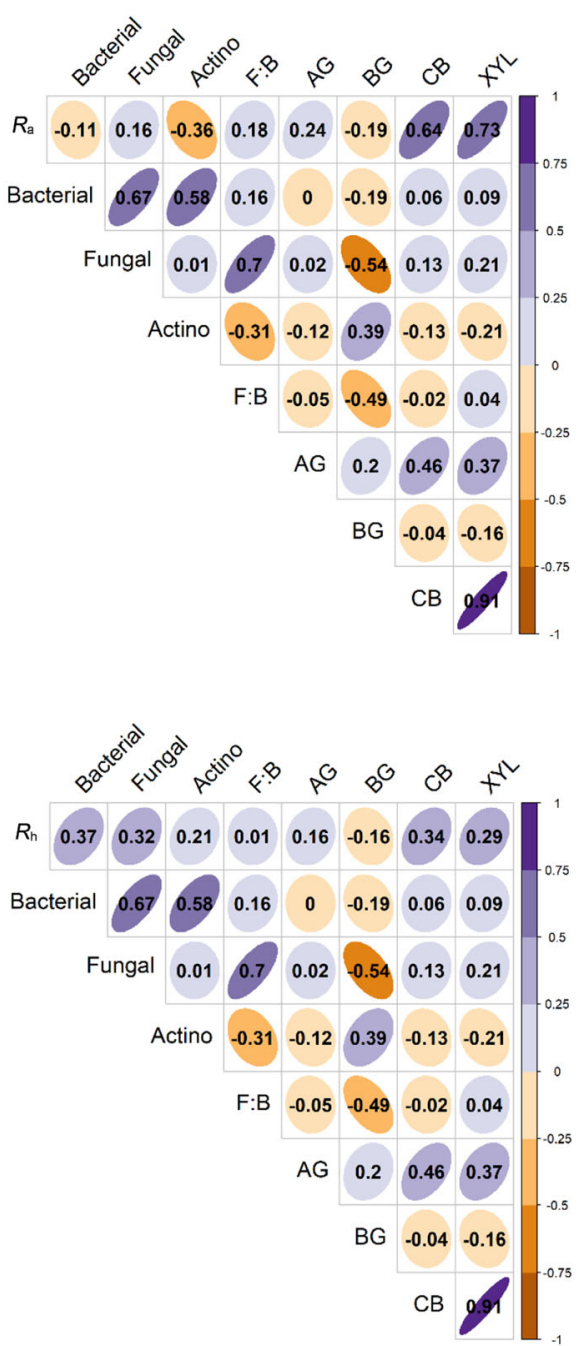

Fig. 4 Soil autotrophic respiration $\left(R_{a}\right)$ and heterotrophic respiration $\left(R_{h}\right)$ in relation to soil properties, soil microbial community, and enzymes activities. The colors show Spearman's rank correlation coefficient and indicate a positive or negative correlation

rates may be largely owing to that $\mathrm{N}$ or $\mathrm{P}$ addition did not induce changes in soil temperature and soil moisture (Fig. S1), which have proven to be responsible for the decline in the $Q_{10}$ values of $R_{\mathrm{s}}$ and $R_{\mathrm{h}}$ under fertilization (Zhou et al. 2006). Nonetheless, we detected that $\mathrm{P}$ addition significantly reduced the $Q_{10}$ value of $R_{\mathrm{h}}$ in the first year, which also had a trend to decrease under $\mathrm{P}$ addition or NP addition in the second year. Given that there were no significant effects of nutrient addition on soil temperature and moisture, the variation of $Q_{10}$ values was probably due to shifts in soil microbial community structure and metabolic pathways (Zhang et al. 2014). It is suggested that the decomposition of soil organic matter decreases due to the formation of recalcitrant compounds, and soil enzyme activities could be inhibited by nutrient additions (Sun et al. 2014). Moreover, fertilization could affect the diversity and community structure of soil microorganisms (Zhang et al. 2018). All of which have a potential to decrease the temperature sensitivity of soil microbial respiration under fertilization.

\section{Conclusions}

Soil respiration $\left(R_{\mathrm{s}}\right)$ and heterotrophic respiration $\left(R_{\mathrm{h}}\right)$ decreased when $\mathrm{N}$ or $\mathrm{P}$ was added separately, but increased when $\mathrm{N}$ and $\mathrm{P}$ was added in combination during 2-year field study. Nitrogen addition reduced autotrophic respiration $\left(R_{\mathrm{a}}\right)$ across 2 years, while $\mathrm{P}$ addition had an inconsistent effect on $R_{\mathrm{a}}$, and $\mathrm{N}$ and $\mathrm{P}$ coaddition increased $R_{\mathrm{a}}$. $R_{\mathrm{a}}$ was predominantly controlled by soil nutrient availability, enzyme activities, and soil dissolved organic carbon, while the variation in $R_{\mathrm{h}}$ was mainly ascribed to the changes in soil microbial community composition and enzyme activities under 


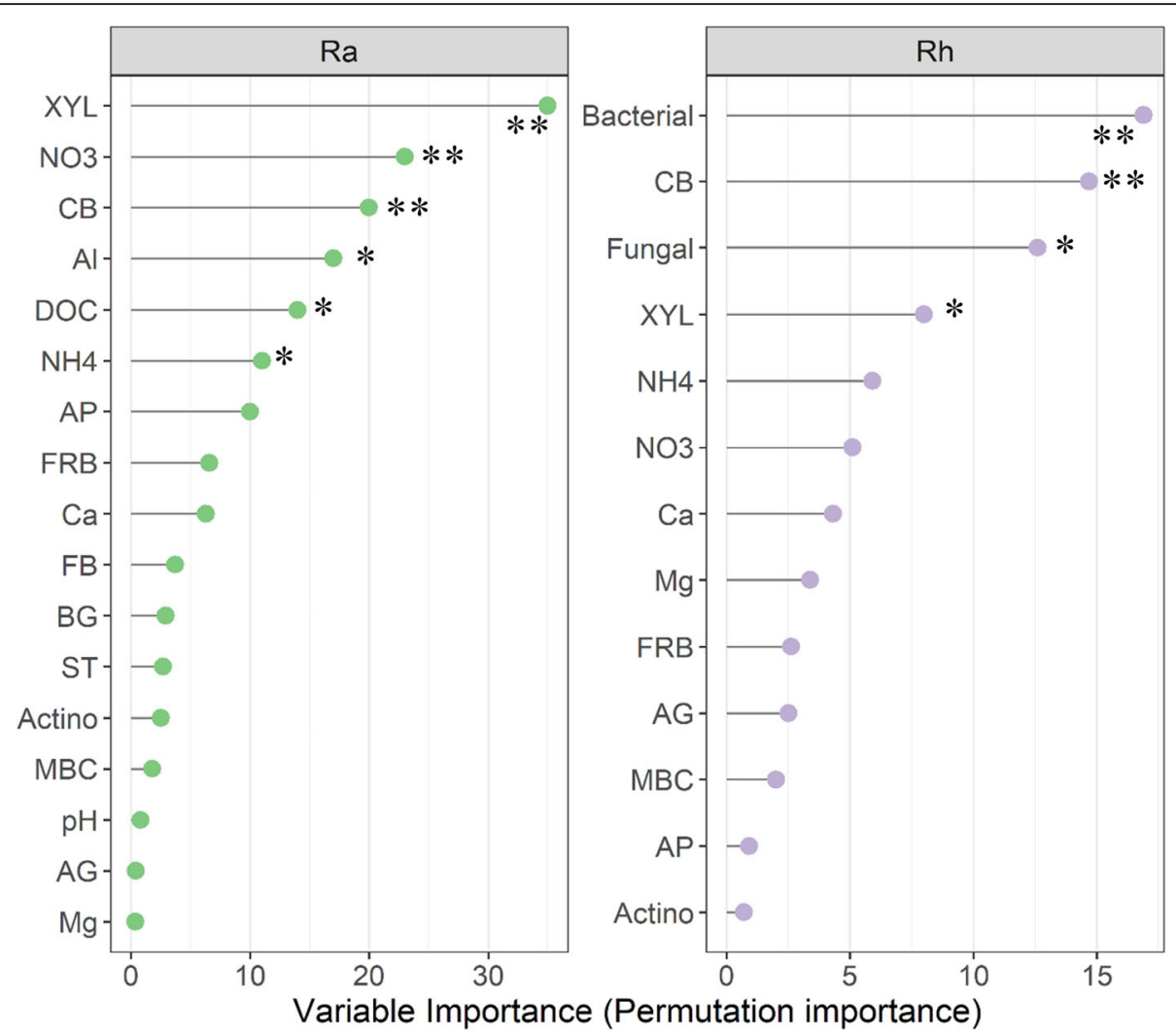

Fig. 5 The relative contributions of driving factors on autotrophic respiration $\left(R_{\mathrm{a}}\right)$ and heterotrophic respiration $\left(R_{\mathrm{h}}\right)$. The variable importance values are derived from 100 runs of random forest analysis including driving factors as moderators in the model. ${ }^{*} P<0.05,{ }^{* *} P<0.01,{ }^{* * *} P<0.001$

fertilization. Temperature sensitivities of $R_{\mathrm{s}}$ and $R_{\mathrm{h}}$ were not affected by nutrient addition except for $\mathrm{P}$ addition significantly reducing the temperature sensitivity of $R_{\mathrm{h}}$ in the first year. Our findings highlight the contrasting responses of soil respiration and its components to $\mathrm{N}$ or $\mathrm{P}$ addition against $\mathrm{N}$ and $\mathrm{P}$ co-addition, which should be incorporated into biogeochemical models to understand and project soil carbon dynamics in the scenarios of aggravated $\mathrm{N}$ and $\mathrm{P}$ enrichment in terrestrial ecosystems. It is also important to note that this experiment was conducted in a short duration, whereas the delayed response of soil respiration to $\mathrm{N}$ or $\mathrm{P}$ addition may lead to different patterns with time. We call for that long-term field experiments are still urgent to disentangle the temporal effects of fertilization on soil carbon cycle processes.

\section{Supplementary Information}

The online version contains supplementary material available at https://doi. org/10.1186/s40663-021-00313-z.

Additional file 1.

\section{Acknowledgements}

Many thanks are due to others for participation or helps in the data collection.
Authors' contributions

Shuli Niu and Jinsong Wang designed research, Junjun Zhang and Yong Li performed research, collected and analyzed data; all authors discussed the results and revised the manuscript. The authors read and approved the final manuscript.

\section{Funding}

This study was supported by National Natural Science Foundation of China (31625006, 31988102 and 32001133), the Strategic Priority Research Program of the Chinese Academy of Sciences (XDA23080302).

Availability of data and materials

The datasets used and/or analyzed in this study are available from the corresponding author on request.

\section{Declarations}

Ethics approval and consent to participate Not applicable.

Consent for publication

Not applicable.

\section{Competing interests}

All authors have no conflict of interest.

\section{Author details}

${ }^{1}$ Key Laboratory of Ecosystem Network Observation and Modeling, Institute of Geographic Sciences and Natural Resources Research, Chinese Academy of Sciences, Beijing 100101, China. ${ }^{2}$ Beijing Key Laboratory of Wetland Services and Restoration, Institute of Wetland Research, Chinese Academy of Forestry, Beijing 100091, China. ${ }^{3}$ Department of Resources and Environment, University of Chinese Academy of Sciences, Beijing 100049, China. 


\section{Received: 9 February 2021 Accepted: 20 May 2021} Published online: 08 June 2021

\section{References}

Adair EC, Reich PB, Hobbie SE, Knops JM (2009) Interactive effects of time, $\mathrm{CO}_{2}$, $\mathrm{N}$, and diversity on total belowground carbon allocation and ecosystem carbon storage in a grassland community. Ecosystems 12(6):1037-1052. https://doi.org/10.1007/s10021-009-9278-9

Bossio DA, Scow KM, Gunapala N, Graham KJ (1998) Determinants of soil microbial communities: effects of agricultural management, season, and soil type on phospholipid fatty acid profiles. Microb Ecol 36(1):1-12. https://doi. org/10.1007/s002489900087

Camenzind T, Hättenschwiler S, Treseder KK, Lehmann A, Rillig MC (2018) Nutrient limitation of soil microbial processes in tropical forests. Ecol Monogr 88(1):4-21. https://doi.org/10.1002/ecm.1279

Chen D, Li J, Lan Z, Hu S, Bai Y (2016) Soil acidification exerts a greater control on soil respiration than soil nitrogen availability in grasslands subjected to long-term nitrogen enrichment. Funct Ecol 30(4):658-669. https://doi.org/1 $0.1111 / 1365-2435.12525$

Chen F, Yan G, Xing Y, Zhang J, Wang Q, Wang H, Huang B, Hong Z, Dai G, Zheng X, Liu T (2019) Effects of N addition and precipitation reduction on soil respiration and its components in a temperate forest. Agric For Meteorol 271:336-345. https://doi.org/10.1016/j.agrformet.2019.03.021

Cheng X, Kang F, Han H, Liu H, Zhang Y (2015) Effect of thinning on partitioned soil respiration in a young Pinus tabulaeformis plantation during growing season. Agric For Meteorol 214:473-482

Cleveland CC, Townsend AR, Taylor P, Alvarez-Clare S, Bustamante MM, Chuyong G, Dobrowski SZ, Grierson P, Harms KE, Houlton BZ, Marklein A, Parton W, Porder S, Reed SC, Sierra CA, Silver WL, Tanner EV, Wieder WR (2011) Relationships among net primary productivity, nutrients and climate in tropical rain forest: a pan-tropical analysis. Ecol Lett 14(9):939-947. https://doi. org/10.1111/j.1461-0248.2011.01658.x

Curiel Yuste J, Janssens IA, Carrara A, Ceulemans R (2004) Annual $Q_{10}$ of soi respiration reflects plant phenological patterns as well as temperature sensitivity. Glob Change Biol 10(2):161-169. https://doi.org/10.1111/j.1529-881 7.2003.00727.x

Cusack DF, Torn MS, Mcdowell WH, Silver WL (2010) The response of heterotrophic activity and carbon cycling to nitrogen additions and warming in two tropical soils. Glob Change Biol 16:2555-2572

Davidson EA, Janssens IA (2006) Temperature sensitivity of soil carbon decomposition and feedbacks to climate change. Nature 440(7081):165-173. https://doi.org/10.1038/nature04514

Deng Q, Zhou G, Liu J, Liu S, Duan H, Zhang D (2010) Responses of soil respiration to elevated carbon dioxide and nitrogen addition in young subtropical forest ecosystems in China. Biogeosciences 7(1):315-328. https:// doi.org/10.5194/bg-7-315-2010

Devaraju N, Bala G, Caldeira K, Nemani R (2016) A model based investigation of the relative importance of $\mathrm{CO}$-fertilization, climate warming, nitrogen deposition and land use change on the global terrestrial carbon uptake in the historical period. Climate Dynamics 47 (1-2):173-190

Dong L, Zeng W, Wang A, Tang J, Yao X, Wang W (2020) Response of soil respiration and its components to warming and dominant species removal along an elevation gradient in alpine meadow of the Qinghai-Tibetan plateau. Environ Sci Technol 54(17):10472-10482. https://doi.org/10.1021/acs. est.0c01545

Edwards IP, Zak DR, Kellner H, Eisenlord SD, Pregitzer KS (2011) Simulated atmospheric $\mathrm{N}$ deposition alters fungal community composition and suppresses ligninolytic gene expression in a northern hardwood forest. PLoS One 6(6):e20421. https://doi.org/10.1371/journal.pone.0020421

Feng J, Zhu B (2019) A global meta-analysis of soil respiration and its components in response to phosphorus addition. Soil Biol Biochem 135:3847. https://doi.org/10.1016/j.soilbio.2019.04.008

Frostegård Å, Bååth E (1996) The use of phospholipid fatty acid analysis to estimate bacterial and fungal biomass in soil. Biol Fert Soils 22(1-2):59-65. https://doi.org/10.1007/BF00384433

Guo H, Ye C, Zhang H, Pan S, Ji Y, Li Z, Liu M, Zhou X, Du G, Hu F, Hu S (2017) Long-term nitrogen \& phosphorus additions reduce soil microbial respiration but increase its temperature sensitivity in a Tibetan alpine meadow. Soil Biol Biochem 113:26-34. https://doi.org/10.1016/j.soilbio.201 7.05 .024
Hagerberg D, Thelin G, Wallander H (2003) The production of ectomycorrhizal mycelium in forests: relation between forest nutrient status and local mineral sources. Plant Soil 252(2):279-290. https://doi.org/10.1023/A:1024719607740

Ilstedt U, Singh S (2005) Nitrogen and phosphorus limitations of microbial respiration in a tropical phosphorus-fixing acrisol (ultisol) compared with organic compost. Soil Biol Biochem 37(7):1407-1410. https://doi.org/10.1016/ j.soilbio.2005.01.002

Jia X, Shao M, Wei X (2012) Responses of soil respiration to N addition, burning and clipping in temperate semiarid grassland in northern China. Agric For Meteorol 166-167:32-40

Jing X, Yang X, Ren F, Zhou H, Zhu B, He J-S (2016) Neutral effect of nitrogen addition and negative effect of phosphorus addition on topsoil extracellular enzymatic activities in an alpine grassland ecosystem. Appl Soil Ecol 107: 205-213. https://doi.org/10.1016/j.apsoil.2016.06.004

Li Y, Niu S, Yu G (2016) Aggravated phosphorus limitation on biomass production under increasing nitrogen loading: a meta-analysis. Glob Change Biol 22(2):934-943. https://doi.org/10.1111/gcb.13125

Li Y, Li Y, Chang SX, Liang X, Qin H, Chen J, Xu Q (2017) Linking soil fungal community structure and function to soil organic carbon chemical composition in intensively managed subtropical bamboo forests. Soil Biol Biochem 107:19-31. https://doi.org/10.1016/j.soilbio.2016.12.024

Li Y, Sun J, Tian D, Wang J, Ha D, Qu Y, Jing G, Niu S (2018) Soil acid cations induced reduction in soil respiration under nitrogen enrichment and soil acidification. Sci Total Environ 615:1535-1546. https://doi.org/10.1016/j. scitotenv.2017.09.131

Liu W, Zhang Z, Wan S (2009) Predominant role of water in regulating soil and microbial respiration and their responses to climate change in a semiarid grassland. Glob Change Biol 15(1):184-195. https://doi.org/10.1111/j.1365-24 86.2008.01728.x

Liu L, Gundersen P, Zhang T, Mo J (2012) Effects of phosphorus addition on soil microbial biomass and community composition in three forest types in tropical China. Soil Biol Biochem 44(1):31-38. https://doi.org/10.1016/j. soilbio.2011.08.017

Liu X, Yang Z, Lin C, Giardina CP, Xiong D, Lin W, Chen S, Xu C, Chen G, Xie J, Li $Y$, Yang $Y$ (2017) Will nitrogen deposition mitigate warming-increased soil respiration in a young subtropical plantation? Agric For Meteorol 246:78-85. https://doi.org/10.1016/j.agrformet.2017.06.010

Liu H, Zhou G, Bai SH, Song J, Shang Y, He M, Wang X, Zheng Z (2019) Differential response of soil respiration to nitrogen and phosphorus addition in a highly phosphorus-limited subtropical forest, China. Forest Ecol Manag 448:499-508. https://doi.org/10.1016/j.foreco.2019.06.020

Ma S, Chen G, Tian D, Du E, Xiao W, Jiang L, Zhou Z, Zhu J, He H, Zhu B, Fang J (2020) Effects of seven-year nitrogen and phosphorus additions on soil microbial community structures and residues in a tropical forest in Hainan Island, China. Geoderma 361:114034. https://doi.org/10.1016/j.geoderma.201 9.114034

Mao Q, Lu X, Zhou K, Chen H, Zhu X, Mori T, Mo J (2017) Effects of long-term nitrogen and phosphorus additions on soil acidification in an $\mathrm{N}$-rich tropical forest. Geoderma 285:57-63. https://doi.org/10.1016/j.geoderma.2016.09.017

Miao Y, Liu M, Xuan J, Xu W, Wang S, Miao R, Wang D, Wu W, Liu Y, Han S (2020) Effects of warming on soil respiration during the non-growing seasons in a semiarid temperate steppe. J Plant Ecol 13(3):288-294. https://doi.org/10.1 093/jpe/rtaa013

Naples BK, Fisk MC (2010) Belowground insights into nutrient limitation in northern hardwood forests. Biogeochemistry 97(2-3):109-121. https://doi. org/10.1007/s10533-009-9354-4

Olsson P, Linder S, Giesler R, Högberg P (2005) Fertilization of boreal forest reduces both autotrophic and heterotrophic soil respiration. Glob Change Biol 11(10):1745-1753. https://doi.org/10.1111/j.1365-2486.2005.001033.x

Pan Y, Birdsey RA, Fang J, Houghton R, Kauppi PE, Kurz WA, Phillips OL Shvidenko A, Lewis SL, Canadell JG, Ciais P, Jackson RB, Pacala SW, McGuire AD, Piao S, Rautiainen A, Sitch S, Hayes D (2011) A large and persistent carbon sink in the world's forests. Science 333(6045):988-993. https://doi. org/10.1126/science.1201609

Peng X, Peng Y, Yue K, Deng Y (2017a) Different responses of terrestrial C, N, and $P$ pools and C/N/P ratios to $P, N P$, and NPK addition: a meta-analysis. Water Air Soil Poll 228(6):197. https://doi.org/10.1007/s11270-017-3383-8

Peng Y, Chen G, Chen G, Li S, Peng T, Qiu X, Luo J, Yang S, Hu T, Hu H, Xu Z, Liu $L$, Tang Y, Tu L (2017b) Soil biochemical responses to nitrogen addition in a secondary evergreen broad-leaved forest ecosystem. Sci Rep 7(1):2783. https://doi.org/10.1038/s41598-017-03044-w 
Peng Y, Song S, Li Z, Li S, Chen G, Hu H, Xie J, Chen G, Xiao Y, Liu L, Tang Y, Tu L (2020) Influences of nitrogen addition and aboveground litter-input manipulations on soil respiration and biochemical properties in a subtropical forest. Soil Biol Biochem 142:107694. https://doi.org/10.1016/j.soilbio.2019.107694

Reay DS, Dentener F, Smith P, Grace J, Feely RA (2008) Global nitrogen deposition and carbon sinks. Nat Geosci 1(7):430-437. https://doi.org/10.103 8/ngeo230

Riggs CE, Hobbie SE (2016) Mechanisms driving the soil organic matter decomposition response to nitrogen enrichment in grassland soils. Soil Biol Biochem 99:54-65. https://doi.org/10.1016/j.soilbio.2016.04.023

Robertson GP, Bruulsema TW, Gehl RJ, Kanter D, Mauzerall DL, Rotz CA, Williams CO (2013) Nitrogen-climate interactions in US agriculture. Biogeochemistry 114(1-3):41-70. https://doi.org/10.1007/s10533-012-9802-4

Savage KE, Parton WJ, Davidson EA, Trumbore SE, Frey SD (2013) Long-term changes in forest carbon under temperature and nitrogen amendments in a temperate northern hardwood forest. Glob Change Biol 19(8):2389-2400. https://doi.org/10.1111/gcb.12224

Song H, Yan T, Wang J, Sun Z (2020) Precipitation variability drives the reduction of total soil respiration and heterotrophic respiration in response to nitrogen addition in a temperate forest plantation. Biol Fert Soils 56(2):273-279. https://doi.org/10.1007/s00374-019-01417-z

Subke J-A, Inglima I, Francesca Cotrufo M (2006) Trends and methodological impacts in soil $\mathrm{CO}_{2}$ efflux partitioning: a metaanalytical review. Glob Change Biol 12(6):921-943. https://doi.org/10.1111/j.1365-2486.2006.01117.x

Sun Z, Liu L, Ma Y, Yin G, Zhao C, Zhang Y, Piao S (2014) The effect of nitrogen addition on soil respiration from a nitrogen-limited forest soil. Agric For Meteorol 197:103-110. https://doi.org/10.1016/j.agrformet.2014.06.010

Sun X, Tang Z, Ryan MG, You Y, Sun J (2019) Changes in soil organic carbon content sand fractionations of forests along a climatic gradient in China. Forest Ecosyst 6(1):1. https://doi.org/10.1186/s40663-019-0161-7

Tang X, Pei X, Lei N, Luo X, Liu L, Shi L, Chen G, Liang J (2020) Global patterns of soil autotrophic respiration and its relation to climate, soil and vegetation characteristics. Geoderma 369:114339. https://doi.org/10.1016/j.geoderma.202 0.114339

Tian D, Niu S (2015) A global analysis of soil acidification caused by nitrogen addition. Environ Res Lett 10(2):024019. https://doi.org/10.1088/1748-9326/1 0/2/024019

Tian D, Jiang L, Ma S, Fang W, Schmid B, Xu L, Zhu J, Li P, Losapio G, Jing X, Zheng C, Shen H, Xu X, Zhu B, Fang J (2017) Effects of nitrogen deposition on soil microbial communities in temperate and subtropical forests in China. Sci Total Environ 607:1367-1375

van Elsas JD, Chiurazzi M, Mallon CA, Elhottova D, Kristufek V, Salles JF (2012) Microbial diversity determines the invasion of soil by a bacterial pathogen. PNAS 109(4):1159-1164. https://doi.org/10.1073/pnas.1109326109

Vitousek PM, Porder S, Houlton BZ, Chadwick OA (2010) Terrestrial phosphorus limitation: mechanisms, implications, and nitrogen-phosphorus interactions. Ecol Appl 20(1):5-15. https://doi.org/10.1890/08-0127.1

Wagai R, Kishimoto-Mo AW, Yonemura S, Shirato Y, Hiradate S, Yagasaki Y (2013) Linking temperature sensitivity of soil organic matter decomposition to its molecular structure, accessibility, and microbial physiology. Glob Change Biol 19(4):1114-1125. https://doi.org/10.1111/gcb.12112

Wang Q, Li Y, Zhang F, He T (2015) Short-term nitrogen fertilization decrease root and microbial respiration in a young Cunninghamia lanceolata plantation. Chin J Plant Ecol 39:1166-1175

Wang Q, Zhang W, Sun T, Chen L, Pang X, Wang Y, Xiao F (2017a) N and P fertilization reduced soil autotrophic and heterotrophic respiration in a young Cunninghamia lanceolata forest. Agric For Meteorol 232:66-73. https://doi.org/10.1016/j.agrformet.2016.08.007

Wang R, Goll D, Balkanski Y, Hauglustaine D, Boucher O, Ciais P, Janssens I, Penuelas J, Guenet B, Sardans J, Bopp L, Vuichard N, Zhou F, Li B, Piao S, Peng S, Huang Y, Tao S (2017b) Global forest carbon uptake due to nitrogen and phosphorus deposition from 1850 to 2100. Glob Change Biol 23(11): 4854-4872. https://doi.org/10.1111/gcb.13766

Wang J, Sun J, Xia J, He N, Li M, Niu S (2018) Soil and vegetation carbon turnover times from tropical to boreal forests. Funct Ecol 32(1):71-82. https://doi.org/1 $0.1111 / 1365-2435.12914$

Wang J, Song B, Ma F, Tian D, Li Y, Yan T, Quan Q, Zhang F, Li Z, Wang B, Gao Q, Chen W, Niu S (2019b) Nitrogen addition reduces soil respiration but increases the relative contribution of heterotrophic component in an alpine meadow. Funct Ecol 33:2239-2253
Wang J, Wang G, Fu Y, Chen X, Song X (2019a) Short-term effects of nitrogen deposition on soil respiration components in two alpine coniferous forests, southeastern Tibetan plateau. J Forestry Res 30(3):1029-1041. https://doi. org/10.1007/s11676-018-0678-6

Wei S, Tie L, Liao J, Liu X, Du M, Lan S, Li X, Li C, Zhan H, Huang C (2020) Nitrogen and phosphorus co-addition stimulates soil respiration in a subtropical evergreen borad-leaved forest. Plant Soil 450(1-2):171-182. https://doi.org/10.1007/s11104-020-04498-0

Widdig M, Schleuss P-M, Biederman LA, Borer ET, Crawley MJ, Kirkman KP, Seabloom EW, Wragg PD, Spohn M (2020) Microbial carbon use efficiency in grassland soils subjected to nitrogen and phosphorus additions. Soil Biol Biochem 146:107815. https://doi.org/10.1016/j.soilbio.2020.107815

Xiao S, Wang GG, Tang C, Fang H, Duan J, Yu X (2020) Effects of one-year simulated nitrogen and acid deposition on soil respiration in a subtropical plantation in China. Forests 11(2):235. https://doi.org/10.3390/f11020235

Xu M, Shang H (2016) Contribution of soil respiration to the global carbon equation. J Plant Physiol 203:16-28. https://doi.org/10.1016/j.jplph.2016.08.007

Yan J, Zhang W, Wang K, Qin F, Wang W, Dai H, Li P (2014) Responses of $\mathrm{CO}_{2}$, $\mathrm{N}_{2} \mathrm{O}$ and $\mathrm{CH}_{4}$ fluxes between atmosphere and forest soil to changes in multiple environmental conditions. Glob Change Biol 20(1):300-312. https:// doi.org/10.1111/gcb.12327

Zeng W, Wang W (2015) Combination of nitrogen and phosphorus fertilization enhance ecosystem carbon sequestration in a nitrogen-limited temperate plantation of northern China. Forest Ecol Manag 341:59-66. https://doi.org/1 0.1016/j.foreco.2015.01.004

Zeng W, Zhang J, Wang W (2018) Strong root respiration response to nitrogen and phosphorus addition in nitrogen-limited temperate forests. Sci Total Environ 642:646-655. https://doi.org/10.1016/j.scitotenv.2018.06.014

Zhang C, Niu D, Hall SJ, Wen H, Li X, Fu H, Wan C, Elser JJ (2014) Effects of simulated nitrogen deposition on soil respiration components and their temperature sensitivities in a semiarid grassland. Soil Biol Biochem 75:113123. https://doi.org/10.1016/j.soilbio.2014.04.013

Zhang TA, Chen HY, Ruan H (2018) Global negative effects of nitrogen deposition on soil microbes. The ISME Journal 12(7):1817-1825. https://doi. org/10.1038/s41396-018-0096-y

Zhang H, Qian Z, Zhuang S (2020) Effects of soil temperature, water content, species, and fertilization on soil respiration in bamboo forest in subtropical China. Forests 11(1):99. https://doi.org/10.3390/f11010099

Zhao B, Wang J, Cao J, Zhao X, Gadow KV (2018) Inconsistent autotrophic respiration but consistent heterotrophic respiration responses to 5 -years nitrogen addition under natural and planted Pinus tabulaeformis forests in northern China. Plant Soil 429(1-2):375-389. https://doi.org/10.1007/s11104018-3702-x

Zhong Y, Yan W, Shangquan Z (2016) The effects of nitrogen enrichment on soil $\mathrm{CO}_{2}$ fluxes depending on temperature and soil properties. Glob Ecol Biogeogr 25(4):475-488. https://doi.org/10.1111/geb.12430

Zhou L, Zhou X, Zhang B, Lu M, Luo Y, Liu L, Li B (2014) Different responses of soil respiration and its components to nitrogen addition among biomes: a meta-analysis. Glob Change Biol 20(7):2332-2343. https://doi.org/10.1111/ gcb. 12490

Zhou S, Xiang Y, Tie L, Han B, Huang C (2018) Simulated nitrogen addition significantly reduces soil respiration in an evergreen broadleaf forest in western China. PLoS One 13:e204661

Zou J, Tobin B, Luo Y, Osborne B (2018) Response of soil respiration and its components to experimental warming and water addition in a temperate Sitka spruce forest ecosystem. Agric For Meteorol 260:204-215

Zhou X, Sherry RA, An Y, Wallace LL, Luo Y (2006) Main and interactive effects of warming, clipping, and doubled precipitation on soil $\mathrm{CO}_{2}$ efflux in a grassland ecosystem. Global Biogeochem cy 20 